\title{
Analysis on China-United States Trade Imbalance from Trade \\ Structure, Mode of Trade, and Trade Policy \\ Jiandong Shi
}

https://doi.org/10.33542/VSS2021-1-03

\begin{abstract}
This paper analyzes the direct cause of China-United States trade war, a trade imbalance between China and the United States, and summarizes the causes of this trade imbalance. I have discussed the trade imbalance from the three perspectives of trade structure, trade mode, and trade policy, which focus on the respective trade policies of China and the United States. Moreover, I have examined the subjective factors affecting the trade imbalance between China and the United States. A significant impact of trade policies on trade imbalance has been demonstrated in this study to call for attention from both sides.
\end{abstract}

Key words: China-United States, trade, imbalance

\section{Introduction}

With the rapid development of China-United States bilateral trade, trade imbalance also causes great concern of the two governments; the China-United States trade imbalance became even more serious since China joined the World Trade Organization. The United States statistics shows that the proportion of the United States trade deficit with China accounts for the gross trade deficit rise to over $30 \%$ in 2008 from about $20 \%$ in 2001 . The United States trade deficit with China reached $\$ 313.424$ billion in 2011. Meanwhile, according to Chinese statistics, the proportion of Chinese trade surplus with the United States accounts for more than $60 \%$ of gross trade surplus; Chinese trade surplus with the United States reached $\$ 201.887$ billion in 2011. On March 31, 2017, Trump signed two executive orders focusing on the United States trade deficit (Shen, 2019).According to the United States official statistics, the total value of the United States imports from China in 2017 was $\$ 505.6$ billion (Liu, 2019). The China-United States trade imbalance greatly impacted bilateral trade development; it even became an important factor that influences the political stability of the two countries. As a country of trade deficit, the United States is particularly sensitive to imbalance appearance aimed at China, and it implements discriminating trade policy against China, resulting in continuously increasing the bilateral trade friction. The United States indicates that the ChinaUnited States bilateral trade imbalance scale continuously increased the unemployment rate 
of the United States manufacturing industry and damaged the sound development of the United States economy. Simultaneously, the United States government adopted trade protectionism measures and highlighted why China-United States trade surplus caused the trade protectionism measure against Chinese governments and derecognized the economic status of the Chinese market. As an important trade partner, China was listed as a key object of anti-illegitimate trade. From the perspective of the actual economic benefits gained, the United States gained self-benefit under the extensive background of global economic imbalance. This global economic imbalance pushed the development of the United States financial industry and the real economy and restrained inland inflation. China-United States trade imbalance will continue to become a hot issue in the world economy in the future: what causes trade imbalance between China and the United States, and how trade structure, trade mode, and the respective trade policies affect this trade imbalance. This paper was decided under such background.

\section{The Structural Factors of the Trade Imbalance between China and the United} States

The factor endowment structure of the two countries determines their division of labor and trade structure. This is the conclusion of trade theory (Samuelson, 1948). As is well-known, the fundamental realities of Chinese and the United States are that China is the world's largest developing country, and the United States is the largest developed country in the world. Moreover, the United States has entered a "post-industrial society," with abundant capital and technology; however, the labor cost is high. Consequently, traditional labor-intensive and resource-intensive manufacturing are transferring to Latin America and Asia. Therefore, the demand for daily necessities of the citizen of the United States only can rely on massive import. Meanwhile, China's comparative advantage lies in the low price of labor and land, but it relatively lacks capital and technology. According to the resource endowment, China should export labor and resource-intensive products to the United States, and the United States should export capital and technology-intensive products to China.

\subsection{The structure of goods traded between China and the United States}

China's exports to the United States are mainly mechanical and electrical products. Household appliances, toys, textiles, base metals, and the products are also the major components of China's exports to the United States. As shown in Figure 1, the export of mechanical and electrical products has always accounted for the largest proportion of China's total exports to the United States from 2007 to 2018, with an average value of $48.1 \%$. The overall trend slowly increases. China's second-largest export to the United States was home toys, with an average share of $12.1 \%$. Moreover, exports of textiles and raw materials 
accounted for an average of $9.1 \%$ of total exports of China to the United States. Meanwhile, exports of base metals and products accounted for an average share of $5.4 \%$.

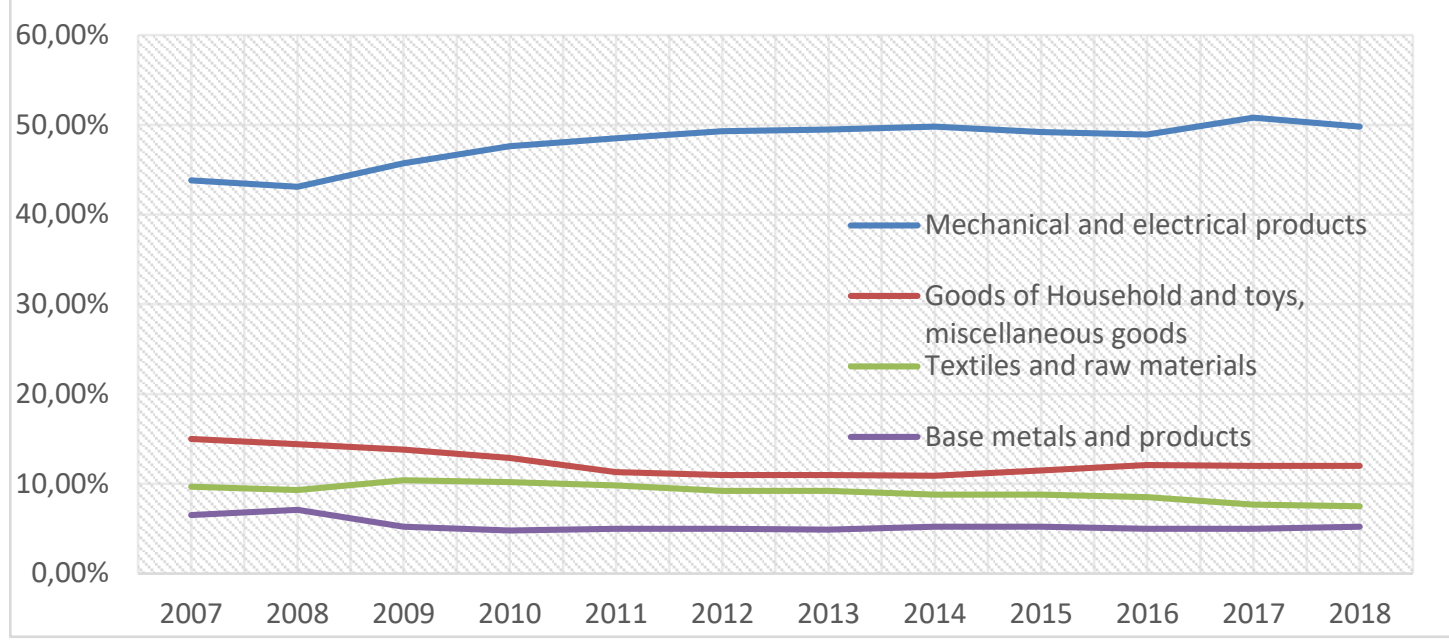

Figure 1: China's exports of major commodities to the United States from 2007 to 2018(\%)

Source: National report of the Ministry of Commerce of China.

Mechanical and electrical products, transportation equipment, and plant and chemical products are China's main imports from the United States. Figure 2 shows the percentage of China's total imports of major commodities from the United States from 2007 to 2018. Among them, the average proportion of mechanical and electrical products is $2.8 \%$, and those of transportation equipment, plant products, and chemical products are $17.1 \%, 11.8 \%$, and $8.7 \%$, respectively.

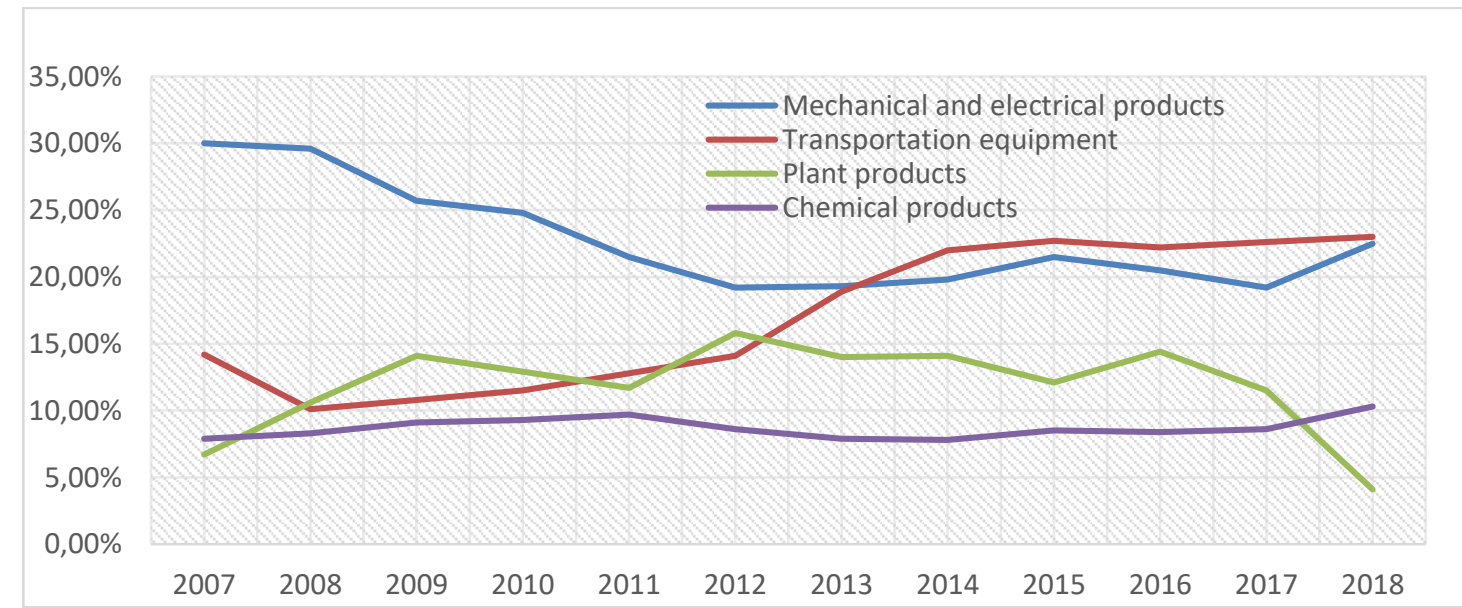

Figure 2: The percentage of China's total imports of major goods from the United States from 2007 to $2018(\%)$

Source: National report of the Ministry of Commerce of China (n.d.) 
As shown in Figure 2, China's mechanical and electrical products purchased from the United States showed a decreasing trend first and then increasing from 2007 to 2018. The import of transportation equipment decreased first and then increased, plant products fluctuated continuously, and the import of chemical products changed relatively slightly.

From the perspective of the structural characteristics of the goods traded between China and the United States, technology and capital-intensive products HS84-85 (mechanical and electrical products) were the main products exported from China to the United States from 2007 to 2018 , accounting for an average of $48.1 \%$. The proportion of mechanical and electrical products in China's imports from the United States is only $22.8 \%$, on average, showing a significant trend of decline. It reflects the structural imbalance in goods traded between China and the United States.

According to the factor endowment theory of Huckster-Ohlin, under the premise of free trade, the trade of goods among countries is determined by their relative factor endowment. Moreover, countries or regions participating in international trade tend to produce and export (import) their relatively abundant (scarce) factor-intensive commodities (Olin, 1933).Therefore, based on the premise of free trade and different factor endowments, economic development, and technological level between China and the United States, China should use its comparative advantage of low cost of labor, land, and other resources to produce and export traditional labor-intensive products. Meanwhile, the United States should produce and export capital or technology-intensive products. However, according to the above data of actual trade statistics, the result is the opposite because of the following.

First, the United States is free to import China's labor-intensive products; however, it has placed many restrictions on its domestic enterprises' export of technology-intensive products to China, which has led to a decline in its export to China and contributed to the trade imbalance (Melvin, 1989; Zhou and Wang, 2005). Second, due to the huge gap in the level of economic development between China and the United States, the demand structure of the two countries' residents is also greatly different. People's consumption choices are closely related to their income level. When the income level is low, most people's expenditure will be concentrated on necessities, such as food. When people's income level is relatively high, they can buy highend products, in addition to necessities, to improve their welfare level. The reality is that most of the labor-intensive goods made in China are necessities of life, whereas the high-tech products made in the United States are high-end products. As we all know, people must buy daily necessities, regardless of their income level. As a result, the United States is bound to import a large number of labor-intensive products produced in China, resulting in a huge trade gap between the two countries (Chu, 2007). 


\section{The Trade Pattern Factors of the Trade Imbalance between China and the United States}

Processing trade is the result of the adjustment of global industrial structure and a form of industrial transmission. With the further development of knowledge economy in the United States, a V-shaped production organization structure similar to the "smile curve" has gradually formed. That is, Japan and South Korea engage in capital and technology-intensive production activities such as R\&D, producing and exporting key parts; Asian and Taiwan produce and export parts system; China engages in labor-intensive assembly and supplies a small number of parts; Hong Kong mainly provides marketing services to overseas markets such as the United States and Europe; and the United States is an export market for products. Becoming the world's processing and manufacturing base, China has formed a trade structure dominated by processing trade on the whole. The raw materials and parts of the processing trade mainly come from South Korea, Taiwan, Singapore, and other Asian countries. Meanwhile, processed products are reexported to the United States and European markets through Hong Kong. According to the statistics of the origin principle, the exporting countries of processed products also transfer to China from these East Asian countries and regions (Xue et al., 1998). 


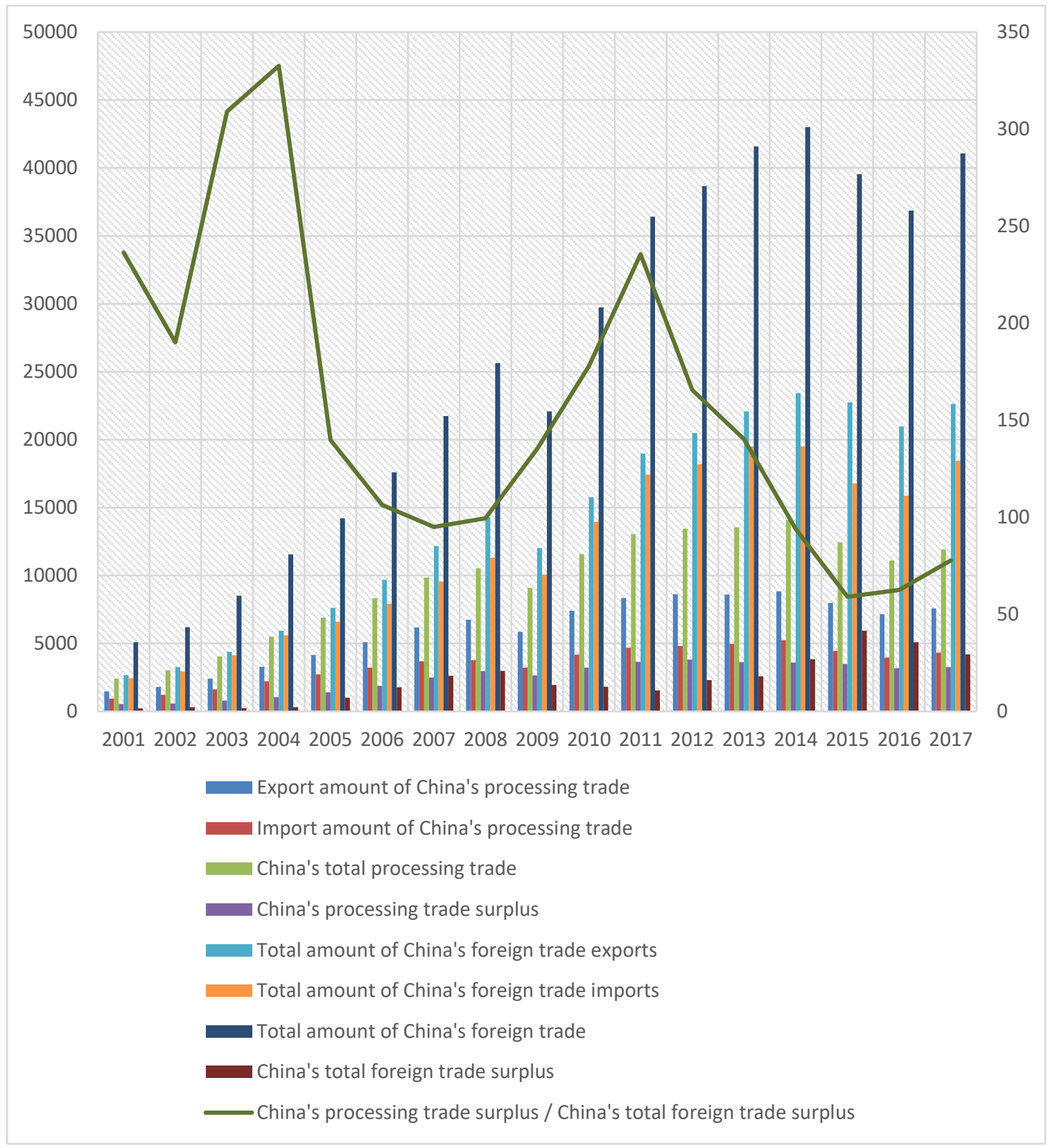

Figure 3: Processing trade mode and surplus ratio of China from 2001 to 2017 (100 million dollars)

Source: China Customs Statistical Yearbook (n.d.)

As shown in Figure 3, first of all, from the change in the amount of growth, the total import and export volume of processing trade in China increased from United States \$241.4 billion in 2001 to United States $\$ 119.13$ billion in 2017 , with an average annual growth rate of $10.49 \%$. Among them, the export volume of processing trade in China increased from United States $\$ 147.43$ billion in 2001 to United States $\$ 758.83$ billion in 2017 , with an average annual growth rate of $10.78 \%$. The import volume of processing trade in China increased from United States \$93.97 billion in 2001 to United States $\$ 432.3$ billion in 2017, with an average annual growth rate of $10.01 \%$. The processing trade surplus in China increased from United States $\$ 53.46$ 
billion in 2001 to US $\$ 326.53$ billion in 2017, with an average annual growth rate of 11.97\%.Second, from the 2001-2017 perspective, China's processing trade surplus in 17 years accounted for over $50 \%$ of the overall trade surplus. Among them, three years of processing trade surplus accounted for nearly $100 \%$; even in the processing trade surplus in 2004 , the share is as high as $332.6 \%$. This means that the year of processing trade in China's foreign trade surplus is more than three times the overall trade surplus. Although the share of processing trade surplus has been declining since 2015, with the expansion of general trade export growth, it still accounts for more than $50 \%$ of the total trade surplus. Therefore, we have sufficient evidence to believe that processing trade is the main source of China's foreign trade surplus.

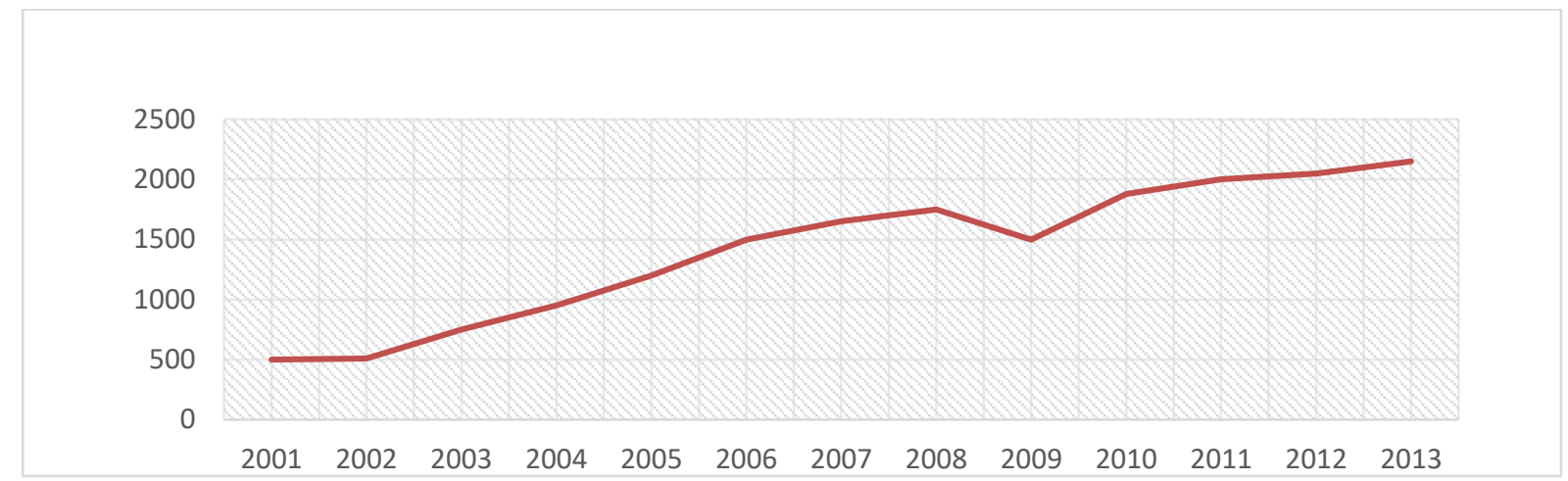

Figure 4: The total amount of processing trade between China and the United States (100million dollars)

Source: China customs database.

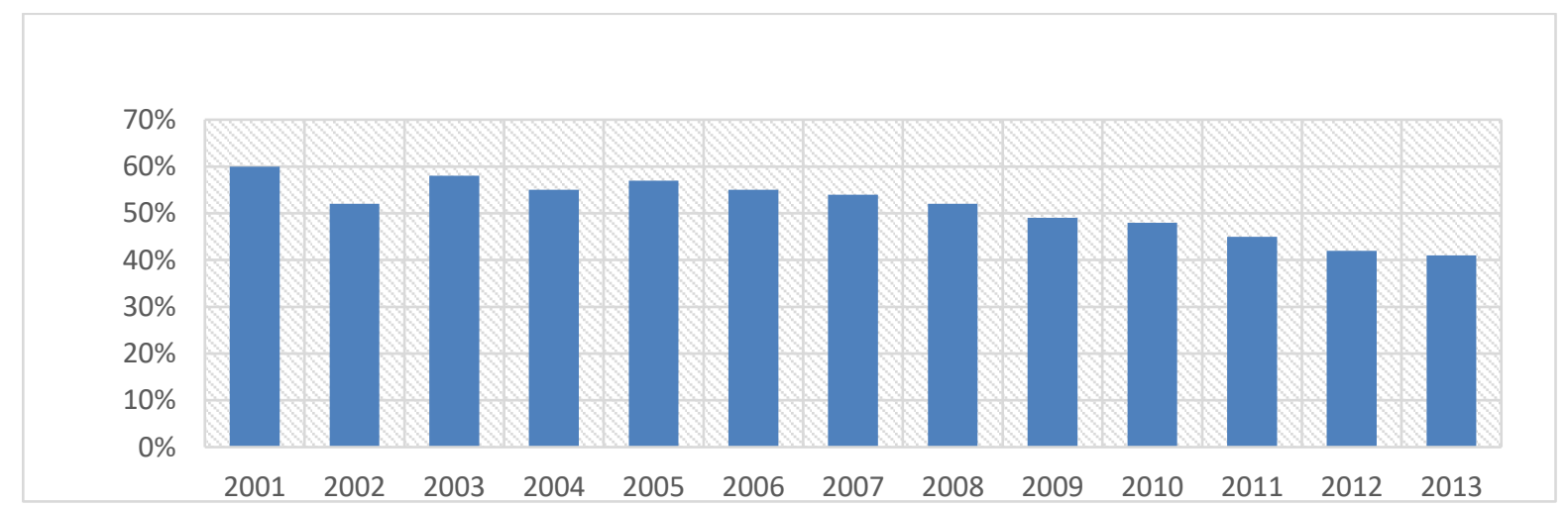

Figure 5: The proportion of the amount of processing trade between China and the United States (\%)

Source: China customs database 
In China's export trade with the United States, the proportion of trade pattern is seriously unbalanced, and the processing trade pattern has always been dominant.

The processing trade volume between China and the United States has been increasing year by year (Figure 4): the import and export volume of processing trade rose from $\$ 50.24$ billion in 2001 to $\$ 215.7$ billion in 2013 . A small decline was observed only in 2009 , when the financial crisis was recovering. However, in 2010, the processing trade returned to the level before the crisis, but the growth rate declined year by year. Figure 5 shows that in 2001, processing trade between China and the United States accounted for $59 \%$ of the total trade between the two sides. By 2013, that share had dropped to $41 \%$. According to Chinese customs statistics, from January to July 2014, China's import and export volume to the United States through processing trade reached $\$ 117.687$ billion, accounting for $38.54 \%$ of China's total import and export volume to the United States in the same period. In general trade, imports and exports to the United States reached $\$ 152.639$ billion, accounting for $49.993 \%$ of China's total imports and exports to the United States in the same period. Therefore, China's trade with the United States has gradually changed the trade mode dominated by processing trade. The traditional processing trade is shrinking, whereas the general trade mode has maintained a good growth trend and become the main trade mode between China and the United States.

The United States, with its advanced production technology and sufficient capital elements, is at the highest end of the world's industrial chain. By contrast, China, with its abundant labor resources and vast market, lacks advanced technology and capital; it is at the lower end of the world's industrial chain. Consequently, China only gains a small amount of profit through processing trade, whereas the United States gains the design and R\&D link of real high profit. Although processing trade solves the problems of employment and foreign exchange reserve in China, it leads to resource waste and eventually affects the adjustment of China's industrial structure. Therefore, China makes great efforts to develop general trade by using export tax rebates. Moreover, it changes the dominant pattern of processing trade and gradually changes the imbalance of trade patterns.

\section{The Trade Policy Factors of the Trade Imbalance between China and the United States}

Grossman and Helpman's (1994) "protection for sale" model is the most significant theoretical contribution of political and economic analysis of international trade so far. In their model, national governments maximize not only welfare but also the contributions they receive from each lobby. They analyzed two levels of strategic interaction between domestic interest groups and government officials, and the strategic interaction between governments in the 
international field. Through the analysis of the non-cooperative and cooperative tariff game model, the protection agency model is a good example of how domestic politics determines the government's national goals (Grossmann and Helpman, 2005).

Deisler (2006) combined economics and politics, highlighted the political logic of United States trade policy, and comprehensively and systematically discussed United States trade politics and policies. He also provided a high degree of insight on new trade protectionism and the political consensus of the two parties in the United States Congress on foreign trade.

Meanwhile, Sheng (2002) applied the theoretical and conceptual framework of international political economy to the analysis of China and clarified the overall framework of China's trade policy decision-making. He also analyzed the government behavior, decisionmaking process, and institutional constraints of China's trade policymaking from three aspects: national goal and authority, domestic interest groups and foreign governments, and international trade system. Moreover, Liang (2006) constructed the general equilibrium model of the United States trade policy towards China and studied this policy from the perspective of the interactive game between China and the United States. Meanwhile, Wang (2006) used the dynamic game model to analyze the political economy of trade friction between China and America. Further, Zhang (2007) analyzed the political and economic factors of the United States trade policy decision from the perspective of national and social interests by establishing the model of the game between the government and interest groups. Wang (2007) proposed an analytical framework of three-dimensional state-market-society interaction and analyzed the political logic behind China-United States economic and trade relations. Moreover, from the perspective of institutional change, Wang (2011) revised and extended the model of trade policy under direct legislation and its decision-making and forming mechanism under the delegation of authority.

Considering the subjective factors that affect the trade imbalance between China and the United States, trade policies adopted by these countries, based on their own economic development, speed up and deepen the trade imbalance between China and the United States, In the absence of effective international economic rules and systems, the trade imbalance between China and the United States is a political and economic behavior aimed at the rapid development of their own economy and the maximization of their economic interests.

After arranging and reviewing the previous studies, it is found that economists and politicians pay excessive attention to trade policies, and conduct an all-sided investigation of trade policies from various perspectives and aspects, which is comprehensive and in-depth. However, the insufficient explanation in the existing literature studies on United States trade policy making for China is shown in: most of the existing literature studies on China-United States trade relations start from pure economic perspective, and conduct analysis in terms of 
issues, such as China-United States trade friction and China-United States trade imbalance, but comprehensive investigations of political and economic factors in trade policies are relatively rare. In the current perspective of political economy analysis, most studies rest on the general analysis of various factors during the decision-making of United States trade policy for China. There are also some scholars who focus on the adjustment of United States diplomatic policy for China during a specific period, or conduct political and economic analysis of the decision-making process in allusion to a specific industry or a specific measure. Thus, in general, few have proposed a systematic and rigorous framework which integrates political and economic factors. Therefore, it cannot account for the deep and decisive factors between the situations of China-United States economic and trade interaction and specific policies, nor can it offer a strong theoretical basis for interpreting the evolution of the United States trade policy for China and predicting the trend.

\section{The foreign trade policy choice of the United States and trade imbalance between China and the United States}

\subsection{United States policy on export control of high-tech products}

The export control policy of the United States began in the 18th century, during II. World War. Because of the national security concerns in the United States, the United States implements export controls of military and supplies to fascist states. After World War II, the United States adopted a policy of export control, economic sanctions, and anti-dumping to the socialist camp headed by the Soviet Union.

From the situation of export control of the United States to China, at the beginning of the People's Republic of China founding, the United States exercised comprehensive control over China's exports. After World War II, the export administration act of the United States Department of Commerce divided export control over foreign countries into eight levels: the strictest control is Z, then S, Y, W, Q, T, P, and V in proper order. In the 1970s, the United States imposed a long-standing trade embargo and a total embargo on China, placing China in the $Y$ category of export controls. In the 1980s, China and the United States eased their relations, and the two countries signed the Shanghai joint communique, which reduced the level of trade control of the United States against China to the V level. After the 1990s, the rapid development of China strengthens the United State's awareness of the crisis. Hence, the United States government began blocking preferential policies for technology export to China and imposed export restrictions on the high-tech fields to China. On the choice of policy, the United States has always prioritized national security and political interests over economic interests, despite China's growing trade surplus with United States. To ensure that the overlord of the world economic status will not be transcended and replaced, the United States control the export of 
high and new technology, which has absolute advantages. It is willing to face the foreign trade deficit increased year by year.

The export of high-tech products from the United States to China can be divided into three levels. First, green goods that do not threaten United States national security can be exported to China after being examined and approved by the United States Department of Commerce. Second, the yellow goods of dual-use technologies must be examined by the US Department of Defense before they can be exported. Third, red commodities representing sensitive strategic technologies are strictly prohibited for export to China.

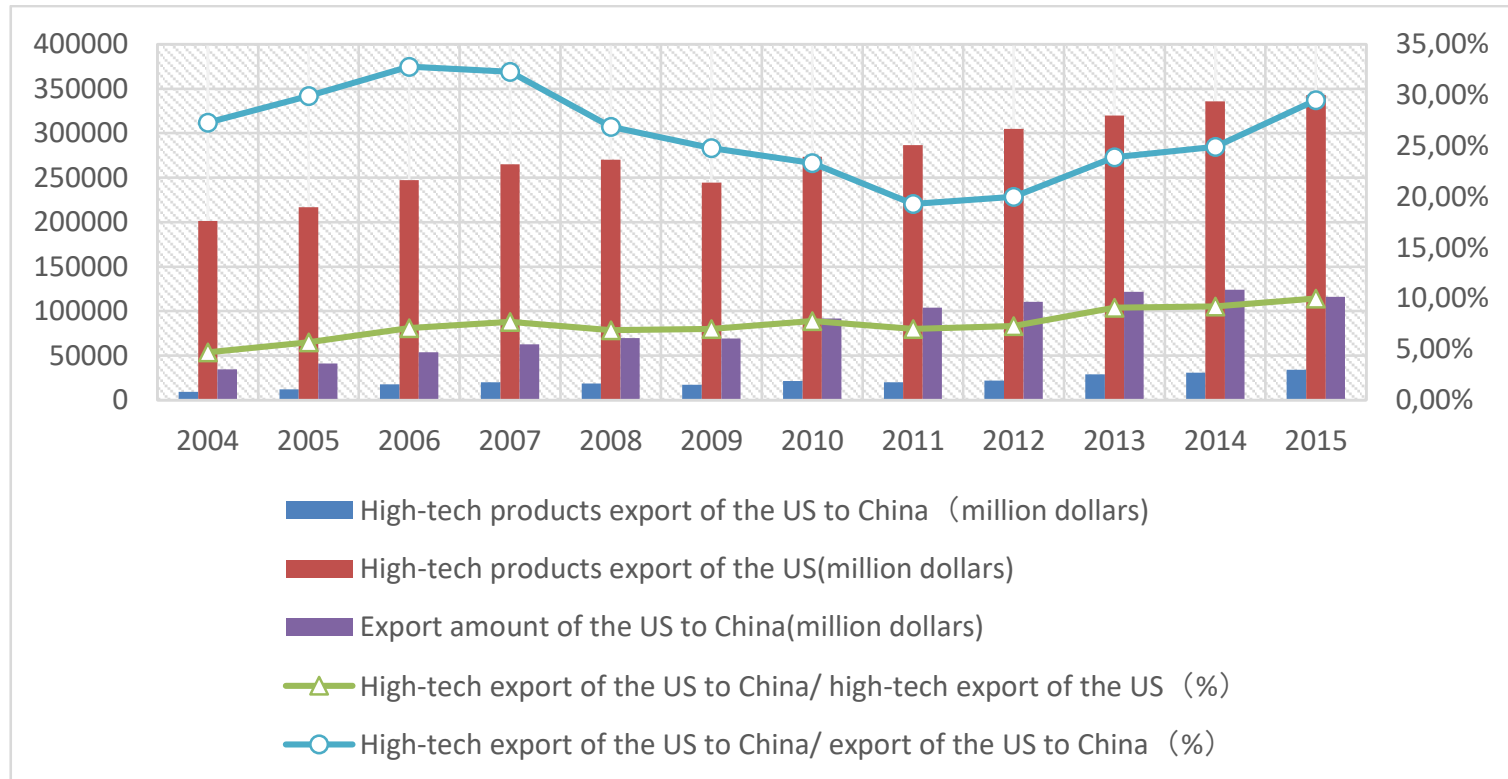

Figure 6: High-tech product export of the United States to China from 2004 to 2015 (million dollars, \%)

Source: Wind Database (n.d.)

Figure 6 shows that the United States high-tech exports to China have been around 20 to $30 \%$, which is still low compared with the proportion of the United States high-tech industry in the economy. Undeniably, China is the largest trading partner of the United States; however, the most competitive high-technology exports of the United States to China accounted for only $4.7 \%$ in 2004 . This proportion rose gradually and reached $10 \%$ in 2015 . However, this is still small compared with China's demand for imports from the United States high-tech industry and its ability to export. Fortunately, the proportion of high-tech exports from the United States to China has increased, indicating that the restrictions on high-tech exports from the United States to China are gradually easing.

From the foreign trade theory, high-tech fields are the comparative advantage industry of the United States foreign trade. However, the export restrictions of high-tech products at different levels imposed by the United States on most countries, especially on China, have greatly reduced the export of US high-tech products to all countries or through other countries' 
detour. When the United States imports a large number of labor-intensive products from China and other developing countries, and oil resources from oil exporters, the division of labor among international industries is broken. This inevitably leads to the trade deficit of the United States and the trade surplus of China. The policy choice of the United States is an important factor causing the current trade imbalance between China and the United States.

Interest groups and the United States export control policies for high-tech products

Interest groups are important forces in the political and economic pattern of the United States. Although they are not in the center of power, they can influence foreign trade policy by exerting pressure on congress, the government, the President, and relevant agencies.

As early as during the United States Revolution, a group of agitators for United States independence had emerged: "The United States is the country where interest groups flourish most." In the 1880 s and 1890 s, as industrialization accelerated, the number of United States enterprise associations exploded. The 1920s were a golden age for interest groups, and influential organizations, such as the USCC, NAM, AMA, NAACP , NUL, NFU, AIPAC, were founded during this period. Since the 1960s and 1970s, under the background of accelerated economic globalization and the passing of the most intense period of the "cold war," United States interest groups have ushered in another period of great development. In 1993, the number of interest groups increased by $50 \%$ compared with that of 1980 to about 23,000 or five times that of 1955 (Zhu, 2003).

Every major issue in the China-United States trade relationship is a bone of contention among American interest groups, who engage in many public relations and lobbying to defend their interests. For example, export control has always been a critical issue in the China-United States trade relations. Two kinds of opinions in the United States support and oppose export control. Especially since the end of the "cold war," different factions have been fiercely debating over the reform of export control system; they are divided into "national security" and "economic security." "National security" believes that the national security must be placed in the core position. It will undermine the United States security if the cutting-edge technology is exported to the countries that may be hostile to the United States. Moreover, if this technology is sold to the unstable regime, these techniques can be used against the United States or its Allies in the future. Relaxation of export controls for short-term commercial gain must not bring disaster to national security. Meanwhile, "economic security" argues that although some equipment and technology exports may be harmful to national security and foreign policy, the current export control measures in the United States are too strict. This may cause declining competitiveness and losing market share. Moreover, some of the United States key industries will suffer because of the stringent restriction on export overseas jobs. Therefore, to strengthen the economic security while defending national security, the export controls must be relaxed. 
The United States business circles represent supporters of the economic security theory. Their criticism of the United States export control policy toward China mainly focuses on the following aspects: (1) the broad range of regulated products harms United States businesses by limiting the export of many products or technologies that have no military application value. (2) Unclear regulatory rules and uncertain approval processes have discouraged Chinese companies to do business with United States companies, thereby increasing the uncertainty of the normal China-United States trading environment. (3) They fail to take full account of the foreign availability of United States technology, and thus, United States companies lost the Chinese market. (4) The overly conservative export control policies of the United States limit the further development of United States multinationals in China, which may cause United States companies to lose their competitive advantage. (5) Current United States export control policies are damaging the United States industrial base and will ultimately undermine the United States national security interests.

Therefore, the business community actively promotes the liberalization of the United States government's export control to China, and its efforts effectively balanced the political influence of the "national security faction." In 2000, the Rand Corporation made the following proposal to the United States President: America's substantial export control interests should be promoted openly, rather than being unstoppable or uncontrollable. In May 2005, the American chamber of commerce in China sent representatives from Beijing and Shanghai to attend the Washington government meeting and jointly appeal to 43 influential officials about timely updating of unnecessary export restrictions for China.

United States foreign trade policy has a remarkable decision-making system, and interest groups play an important role in the decision-making and implementation. The interest groups that play an important role in the decision-making and implementation of China's trade policy are mainly industrial and commercial interest groups, labor organizations, and ideological interest groups. With the deepening development of Sino-US economic and trade relations, the interest groups concerned with China issues are becoming diversified. They conduct lobbying activities, political donations, elections, and public opinion-making according to their own positions. Moreover, they strive to realize their own interests and those of their members. The complexity of China-related interest groups determines that the United States trade policy toward China is periodic and volatile. 


\section{The choice of China's foreign trade policy and trade imbalance between China and the United States}

\subsection{China's import substitution and export-oriented foreign trade policy}

During the founding of the People's Republic of China and the implementation of the reform and opening-up policy in 1978, China was in a relatively closed stage of selfdevelopment. After the reform and opening up, China implemented import substitution and export-oriented foreign trade policies to promote the development of the domestic economy and the increase in foreign exports.

From the perspective of the policy tool of import substitution policy, in the early 1980s, China implemented high tariffs and an import quota and license system to guarantee China's foreign exchange reserves by restricting imports. Since the 1990s, with the implementation of export-oriented policies and the increase in the scale of foreign exports, the types of commodities subject to import license administration in China have been continuously reduced. Moreover, since the beginning of the 21 st century, China has lifted the import restrictions imposed by license.

The export-oriented policies tools are mainly composed of export subsidies, export rebates, and export credits. At the beginning of the reform and opening up, Chinese enterprises export competitiveness is weak; hence, some export enterprises are in the red. To improve the production technology of domestic enterprises and the management ability and lead the enterprises to learn from developed countries and those with strong competitive strength, China's national finance subsidizes trade losses, which played an important role in the early stage of China's foreign trade. Simultaneously, the product tax, value-added tax, and consumption tax paid by export enterprises shall be subject to a tax refund administration to reduce the tax burden on export enterprises, guide domestic enterprises to develop export business, and participate in international competition. Later in the 1990s, China's export situation takes a turn for better. In particular, to help enterprises realize self-sustaining, China reduced and eventually eliminated the export subsidy policy to foreign trade enterprises. Moreover, the export tax rebate rates were cut; however, after the Asian financial crisis in 1997 and the subprime crisis in 2008 , the export tax rebates were reimplemented. Nonetheless, the overall trend is that the export-oriented policy gradually weakening.

From the perspective of China's own situation, the choice of import substitution and export-oriented policy is based on its own interests and economic development. First, China's import substitution and export-oriented policies are the result of foreign experience. From the 1950 s to the 1980s, Japan had transferred the import substitution model to the implementation of an export-oriented model, and it realized the rapid development of the economy. Then, four Asian tigers also followed the experience of Japan, expanded their scale of export, and 
became a moderately developed country (region). Thus, export-oriented policy succeeded in many Asian countries (regions), which followed the templates and made reference to China's development. Second, China's import substitution and export-oriented policy are the direct choice to solve the problem of foreign exchange shortage. In the early days of reform and opening-up, China's foreign exchange reserves were relatively small. Before 1980, China's foreign exchange reserves were less than $\$ 1$ billion at most. In 1980, they were $-\$ 1.3$ billion; this serious shortage of foreign exchange reserves poses a threat to the national security. At that time, China learned from the experience and lessons of Latin American countries that experienced debt crisis caused by excessive external debt. Moreover, China's important goal at that time was to increase foreign exchange reserves by exporting.

The implementation of China's export-oriented foreign trade policy plays an important role in the development of China's economy. First, export-oriented policies have driven China's economic growth. Export-oriented policies strongly supported the growth of China's exports and promoted the rapid development of other domestic sectors through the export sector. Thus, China's economy has achieved rapid development since the end of the war and has undergone earth-shaking changes in just a few decades. Second, export-oriented policies have eased China's tight job market and insufficient consumption demand. With China's large population, backward economic development, and insufficient consumer demand, the development of export enabled China's human resources and resource advantage to play. The foreign consumer demand pull the development of the supply side of the domestic industry, alleviated the employment difficult situation at the time, increased the residents' income, and boosted the growth of China's own spending power. Third, export-oriented policies have increased China's foreign exchange reserves and prevented China from suffering a major financial crisis. With the expansion of exports, China's foreign exchange reserves gradually increased. In 1997, China's official foreign exchange reserves reached $\$ 139.89$ billion, which is 837 times the level at the beginning of the reform and opening up in 1978. By the end of 2015 , China's foreign exchange reserves reached $\$ 3,330.36$ billion, 23.8 times the level in 1997, accounting for $30.5 \%$ of the global total foreign exchange reserves. Because of its abundant foreign exchange reserves, China did not experience a major financial crisis during the Asian financial crisis in 1997 and the rapid development of international hot money, thus creating a favorable external environment for China's economic and financial development (China Statistical Yearbook).

Additionally, under the export-oriented foreign trade policy, the rapid development of China's export will inevitably bring some negative effects on China. These negative effects are mainly reflected in the formation of China's relatively extensive economic growth mode, high dependence on foreign trade, slow development of domestic demand, especially consumer 
demand, serious energy consumption and environmental pollution, and low monetary policy independence.

\subsection{China's foreign investment policy of encouraging export}

To acquire capital, more high-quality technology, and management level by foreign investment, China has implemented more preferential encouragement policies for foreign investment than for Chinese enterprises. An example of these encouraging policies is foreign exchange loans from foreign Banks in China that may be converted into Yuan. Another example is the preferential policies in taxation, environmental protection, and access to credit to attract foreign capital provided by all local governments. For local governments, foreign investment is a relatively low-cost way to boost local economic growth; it can also maximize the political utility of the local government during its term of office. Moreover, because of China's capital controls, the import substitution policy adopted by China to prevent payment crisis makes it difficult for domestic economic organizations and individuals to meet their import needs. Even if China had the money, the cost is high for local governments, and realizing these needs is difficult. The way of foreign investment avoids the problem of exchange and meets the import demand of foreign equipment.

When China was short of funds, technology, and equipment, the encouraging policies of foreign investment increased China's export scale. Moreover, the technological level and management ability of Chinese enterprises were significantly improved, and the growth rate of China's economy was accelerated. However, the number of foreign exchange funds and the destruction of resources and environment are notable.

The choice of national trade policies of China and the United States has an important influence on the direction and degree of the trade imbalance between China and the United States. However, both the United States's export control policies of high-tech products and China's export-oriented policies are the policy choices based on their own economic interests and national security at that time. These policies are more beneficial than harmful to the country itself, but the effect of these policies on major trading partners is to promote imbalances in their trade and the global economy. Do these policies do more good for them than harm for the world economy as a whole? In the absence of an international policy coordination mechanism, the global economic imbalance is the political and economic behavior of each country aiming at the rapid development of its own economy and the maximization of its economic interests, which objectively produces the synthetic fallacy of global economic development. 


\section{Conclusion}

During the process of making United States trade policies for China, international factors and China factors are playing a significantly prominent role. In the context of global production system, China and the United States have become the most important parts of the global production system. Notwithstanding that China and the United States play a respectively asymmetrical role in their policy making, China is increasing its influence on United States domestic and foreign policies. For instance, China's increasingly rising status in the global production system and the international trade system has made the United States government and transnational businesses attach great importance to their commercial interests in China, thus making the whole policy for China gradually cautious and proactive.

The findings of Statistical data analysis reveal that the structural imbalance in goods traded between China and the United States results in a huge trade gap between the two countries.

Meanwhile, interest groups and the United States export control policies for high-tech products, China's import substitution and export-oriented foreign trade policy, and China's foreign investment policy of encouraging export speed up and deepen the trade imbalance between China and the United States. In the absence of effective international economic rules and systems, the trade imbalance between China and the United States is a political and economic behavior aimed at rapidly developing their own economy and maximizing their economic interests.

Trade imbalance is dynamic and frequent, whereas trade balance is a short-term phenomenon and relative. The trade between various countries has always been incompletely balanced. Even if economic globalization exerts some balanced effect on the distribution of trade flow between countries, forming a completely balanced trade pattern is impossible. However, the trade imbalance between China and the United States has become the immediate cause of the China-United States trade war, thus affecting the confrontation of both sides in other fields. Thus, the policymakers adopted subjective détente trade policies to contribute to the improvement of bilateral trade relations and even the improvement of the relations in all aspects.

\section{References}

CHEN, D. 2007. Strategies for promoting the relative balance of trade between China and the United States and the prospect, Economic Affairs, p. 4

China Customs Statistical Yearbook (2017) [online] Available at:

http://tongji.cnki.net/kns55/Navi/HomePage.aspx?id=N2013040099\&name

CHU, J. 2007. A study on the causes of trade imbalance between China and the United States, Journal of North Economy and Trade, 10 
DEISLER. 2006. United States trade politics, Beijing: China Market Press.

GROSSMAN, C. AND HELPMAN, E. 1994, Protection for sale, American Economic Review, 84, p. 833-850

GROSSMANN, G. M. AND HELPMAN, E. E. 2005, Interest groups and trade policy. Translated by Z. Li. Beijing, Renmin University of China Press, p. 201

LIANG, B. 2006 The balancing mechanism of U.S. trade policy decisions with China. Beijing: china social sciences press.

LIU, Z. 2019. The China-United States trade war and future economic relations, Translated by J. YU. CHINA: Chinese University of Hong Kong press, p. 4.

MELVIN, J.R. 1989. Trade in producer services: A Heckscher-Ohlin approach, The Journal of Political Economy, 97(5), p. 1180-1196.

National Report of the Ministry of Commerce of China, 2017 [online] Available at:

https://countryreport.mofcom.gov.cn/

OLIN, B. 1933 Interregional and international trade Cambridge: MA Harvard University Press, p. $179-251$.

SAMUELSON, P. A. 1948. International trade and the equalization of factor prices, Economic Journal, 58(230) , p. 163-84

SHEN, G. 2019. The focus and new trends of trade frictions between the United States and China, International Business Research, p. 7

SHENG, B. 2002 Political and economic analysis of China's foreign trade policy, Shanghai: Shanghai People's Publishing House.

WANG, X. 2011.The decision-making mechanism and forming factors of United States trade policy towards China, Doctoral dissertation, Nankai University

WANG, Y. 2007. Sino-US economic and trade relations, Beijing: China Market Press.

Wind database. 2018. [Online] Available at: https://www.wind.com.cn/en/edb.html

XUE, R., JIA, H., ZHAO, Y., AND XU, J. 1998 Economic globalization and origin statisticsReview of statistical differences in trade between China and the United States, International Trade Issues, Phase 7, pp. 36-45.

ZHANG, J. 2007. Analysis of the factors determining the United States trade policy towards China . Doctoral dissertation, Shanghai Academy of Social Sciences

ZHOU, S. AND WANG, L. 2005 China-United States economic and trade relations have been progressing rapidly amid frictions, International Issues, (12), p. 9-13

ZHU, L. 2003. A study on the reason of the prosperity of American interest groups, Journal of Henan Normal University (Philosophy and Social Sciences Edition), (1) 


\section{Contact address}

PhD student of the Doctoral School of Public Administration Sciences University of Public Service

2 Ludovika Square, Budapest, 1083, Hungary

E-mail: shijiandong1101@qq.com 